\title{
Framing of Armed Conflicts between the Two Nuclear States of South Asia
}

\author{
Noor-ul-Ain Shahid* \\ Muhammad Ashfaq** \\ Javaria Zubair***
}

\section{SUMMARY}

The current study investigates the framing process through the lens of the causal responsibility and the subject matter adopted by Pakistani print news media during the armed conflicts after the Pulwama assault in February 2019. With the help of the census approach, 282 opinions and editorials were collected from a population of 1,321 published items from six English newspapers. The findings show that Pakistani print media outlets extensively used the individual causal responsibility frame, while the social responsibility frame was used less in numbers. The content analysis reveals that the subject matter of awareness was extensively used in media content during the Pulwama assault and its aftermath. The observations are examined from the perspective of journalistic preferences in selecting specific frames during the framing of regional and global armed conflicts.

Keywords: armed conflicts, framing, content analysis, print media, Indo-Pak conflicts, op-ed coverage, Kashmir, media role

\footnotetext{
* Noor-ul-Ain Shahid, MS Media Sciences, Department of Arts \& Media, Foundation University Islamabad

** Muhammad Ashfaq, Corresponding Author, Assistant Professor, Department of Arts \& Media, Foundation University Islamabad, e-mail: muhammadashfaq@msn.com *** Javaria Zubair, MS Media Sciences, Department of Arts \& Media, Foundation University Islamabad
} 
Medij. istraž. (god. 27, br. 1) 2021. (29-48)

\section{Introduction}

Relations between India and Pakistan the two dominant powers in South Asia have always remained poignant since their Independence from the subcontinent but the Pulwama assault on 14th February 2019 on Indian CPRF soldiers convey brought the two nations to the brink of a war that has not been a witness in years. The major bone of contention between the two countries is the disputed region of Kashmir (Ahmed \& Ashraf, 2019). The attack was carried out within Indian-occupied Kashmir but its aftermath by the Indian government and forces resulting in an airstrike on Balakot increased the threat of South Asian peace instability and security. For all past conflicts and attacks on Indian soil, Indian officials have never shied away from blaming Pakistan for funding and carrying out acts of terrorism in the country. However, the Pulwama attack in February 2019 was carried out by an Indian Kashmiri (Pegahi, 2020). A young boy reportedly twenty years old Adil Ahmad Dar was a resident of a village located near Pulwama, where he attacked the Indian convoy. The attack was a result of constant humiliation and torturing by Indian forces in Jammu and Kashmir. It was stated by Ahmad Dar's parents that he was previously beaten by Indian forces multiple times for falsely accusing him of throwing stones on Indian personnel (Pegahi, 2019). The kargil war between Pakistan and India on May-July 1999 was a defining moment in Indo-Pak as both countries recently became nuclear weapon holders after successful nuclear tests. The wrath and outrage of People living in Indian occupied Kashmir have been expanding in recent years against Indian persecution. The protests of locals saw their peak when in a 2016 gunshot battle, Indian soldiers killed a Hizbul Mujahideen militant leader Burhan Muzaffar Wani of Jammu and Kashmir (BBC, 2019). Excessive abuses of basic human rights in Indian held Kashmir by the Indian government and security forces, which was also emphasized in UN report in 2018 including operations namely Armed services special powers act and operation all out in 2017 continuing till 2018 to allegedly clearing out Jaish-e-Mohammed outlets in Jammu and Kashmir has spurred outrage in people of Jammu \& Kashmir. Since 2017 huge number of Indian troops were deployed in $\mathrm{J} \& \mathrm{~K}$ and these years were considered the most bloodstained years in the history of Kashmir. Immense number of local individuals and militants were killed in conflicts between Indian soldiers and locals in the name of operations. As a result, enormous support was given by people of Jammu and Kashmir to the rising militant groups (Feyyaz, 2019). Pulwama-Balakot episode was the fifth significant armed conflict between nuclear weapons wielding neighboring nations. Both states come dangerously close to nuclear war in response to the external border crises of 2001-2002 and the 2008 Mumbai catastrophe, which were sparked by terrorist outlets operating from Pakistan (Carranza, 2020; Yusuf, 2019). India openly claimed that they destroyed five out of six targets during their airstrike in 
Balakot which is still disputed as it was not verified by international analysts whereas the Pakistan air force did shut down one of the Indian jets in the continuing dogfight and also captured an Indian pilot who was later sent back as peace gesture. Information was released that India may have threated to attack in the response of Pakistan's retaliation of Balakot attack with missiles drop off in Pakistan territory considering if the arrested pilot was not returned by Pakistan, which was also confirmed later my Indian prime minister Narender Singh Modi in an election campaign (Miglani \& Jorgic, 2019; Rej, 2019; Sharma, 2019). Since the two armed conflicts between two countries after Pulwama attack, both India and Pakistan have exchanged threats wagging war against each other. Incidents like these that holds national and international interest are often given extensive media coverage across all platforms. The event, as well as the ensuing armed conflicts, were widely covered by local, regional, and international media (Feyyaz, 2019). Many analysts and scholars looked Pulwama and aftermath from the angle of Modi's pre-election campaign to gather voters support in upcoming elections to tone down his own party failures. Experts asserted that Pulwama attack was a pre-planned operation by the Indian government to gain support of public on the name of patriotism by apparently shutting down terrorist groups and Pakistani aircrafts. And for a short while, it was assumed that the BJP government was successful in its aim of diverting attention from the interstate problems arising in its governance. Another possible reason to stage the Pulwama incident put forward by several analysts was the opening of the Kartarpur corridor by Pakistan for the Indian Sikh community. Since the day Pakistani officials announced the opening of corridor on the 550th birth anniversary of Guru Nanak, the founding father of Sikh community Pakistan has been receiving positive response from Indian Sikh community and on international forums it was considered and welcomed as peace gesture from Pakistan. But Pulwama incident and the armed conflicts that happened after that created a setback for the peace environment it created which can be considered the main aim of the incident. All these hypothetical approaches need critical analysis of India Pakistan current relations and their history as nations. In conflict duration, which encompasses national and international interests, it is believed by scholars that media presents news consisting of ideas and beliefs of their affiliated government and political systems (Dijk, 2006; Pandit \& Chattopadhyay, 2017). A much as media is considered to present unbiased content in front of the audience, during the national crisis and conflicts media directly involves in news building process keeping in mind the values endorsed by the ruling regime, making news from the point of view of "us" and "them" (Mihelj et al., 2009). Studies indicate that media use frames in the coverage and reporting of international issues like armed conflicts by highlighting certain aspects in front of the audience (Bennet, 1990; Chang, 1988; Kim \& Jahng, 2015). Frames are set to have a deep impact on the general public if are aligned with the intentions of the 
movements. This involves giving a believable description of the events happening and suggesting their solutions as well. Media have a very crucial role in the selection of news and resources which mainly have an impact on how the news is framed (Kim \& Jahng, 2015). In recent years, journalistic practice in framing certain issues has been widely studied in different professional systems of different countries. There is a growing body of literature that focuses on the journalistic role in promoting their affiliated political agenda, however, there is still a need of in-depth study on to what extent editors/ journalists use their content making power to frame specific scenarios (Cook, 2000; Marques et al., 2019; Thesen, 2017). Given the salience of news frames in the reporting of conflict scenarios, this study is set out to examine framing process adopted by Pakistani media in framing of armed conflict after Pulwama attack of February 2019. The current study draws from other works which analyzed editorials in a special context and extend its dimension in quantitative content analyses of editorials page of daily coverage by six newspapers; The News, Dawn, Express Tribune, Daily Times, Pakistan Today and The Nation of two armed conflicts after Pulwama attack; Balakot airstrike and Pakistan retaliation.

\section{Kashmir: A bone of contention}

The impulsive relationship between India and Pakistan is often bolstered by relentless military propaganda, criticism in every open forum, and involvement in crossborder military operations. For a long time, academics, foreign relations researchers, and political analysts both locally and internationally have been interested in studying Indo-Pak relations. Scholars believe that the unresolved problem of Kashmir is the source of conflict in India-Pakistan relations (Mitra, 2001). Since India and Pakistan's independence, the Kashmir valley has been a point of controversy between two neighboring countries. During the British existence from the sub-continent and the independence of Hindus and Muslims, independent states like Kashmir were given a choice of joining either Indian or Pakistan side. Then the ruler of Kashmir hesitated in opting for any of the given options and thus region remained disputed between the two countries (Mukherjee, 2016). Over the years, the Indian government has been aggressively trying to force the Kashmiri population to join Indian territory. According to analysts, the Kashmir issue is rightfully so composite since both India and Pakistan have been constantly indulged in winning the region (Mukherjee, 2013, 2016). The difference of opinion over the disputed state of Jammu and Kashmir has been both a reason and repercussion of the building rivalry between both countries (Paul, 2005; Pegahi, 2020). The founding thought behind Pakistan was to make an independent state for the Muslim majority of the subcontinent as they were uncertain to be given equal rights in the sub-continent. In the 
light of this equation, the Muslim majority state of Kashmir should have been part of Pakistan fair and square, but the valley remains disputed to date between India and Pakistan. Although both neighbors have not escalated conflict in a full-blown war, but cross border firing, minor strikes, and blame the other for supporting extremist and militant attacks in each other countries has been seen for the longest time. However, a major obstruction in the India and Pakistan relations and ability to hold stability in clashes over Kashmir took place right after both countries were declared nuclear-armed countries. Nuclear experimentation was carried out in South Asia by both countries which by some scholars, further originates the tensions between India and Pakistan (Mukherjee, 2016). After both India and Pakistan declared themselves nuclear powers scholars argued on the impact of this development on south Asian stability (Rej, 2019) and the disputed territory of Kashmir. The Pulwama-Balakot crises in 2019 draw the attention of scholars, international analysts, and political leaders towards the core issue of Kashmir that resides behind every IndoPak conflict. Kashmir being the dangerous turning point between the two countries requires a serious policy modification for the restoration of peace in South Asia and the economic development of India and Pakistan. Taking everything into account, the Kashmir issue must be resolved through constructive means and both countries have to mutually engage or through intervention and come to terms with each other regarding conflicts that haunt millions of people of both countries.

\section{Media and Conflict}

Public perception of wars and conflicts greatly depends on how media gives coverage to certain issues and conflicts. Due to this reason, it is important to understand how media develops and reports conflicts. Now and then mass media is seen trapped in difficult circumstances during conflicts and crises. In conflict situations, media is considered to either promote peace process or emphasize conflict, growing tensions between rivalries (Roluahpuia, 2016). This peace-building ability was well used in the reporting of Northern Ireland conflicts by prominent media houses across the globe including BBC, Irish news media, and Ulster electronic media (Rid, 2019; Wolfsfeld, 2001). Another study conducted by Bratić (2005) concluded that in the process of contributing towards peacebuilding during conflicts, combined efforts have been carried out by multiple media outlets across countries around the globe (Bratić, 2005). The same sort of combined venture was initiated by two leading media groups; Jung group pf Pakistan and Times of India, India. Both media houses are considered to have an aggressive set of minds by political analysts towards reporting, peace-promoting efforts coming from these media outlets came out a bit shocking (Rid, 2019). However, it depicts the peace-promoting efforts journalists 
are taking to eliminate conflict effects. Studying media's role in promoting peace in war situations revealed the direct influence media reporting of had on audience. During conflicts of Bosnia and Rwanda in 1990's researchers concluded that media specifically emphasized on promoting conflicts while on the same hand it also endorsed the resolution of conflicts through dialogue (Schoemaker \& Stremlau, 2014). The ways and mediums with which media construct contributes and spread information regarding conflict had also changed drastically over the decade (Meyer et al., 2017). Over the years, the ratio of internationalized conflicts causing destructiveness has seen a massive hit among countries. The process of news construction is based on journalistic routines and practices as well as influence from some external factors (Shoemaker \& Reese, 1996), however, Hoxha \& Hanitzsch (2017) argue that besides following professional news building process and authentic news, while reporting conflict news some journalists count on mostly on their inbuilt understanding of a conflict and includes objectional ways of gathering news from unreliable sources (Hoxha \& Hanitzsch, 2017). They concluded in their study that fresher badge of journalist is more focused on gathering conflict information from social media sights whereas the experienced and practiced journalists rely on their trusted and authentic sources for news content. Scholars fears that this difference in conflict reporting neglects the dense and troublesome truths that manifest within conflict dynamics.

\section{News Framing and Frame Building}

Frames are communication tools that identify, diagnose and administer problems through the marking, classification, and interpretation of individual experiences (Goffman, 1986; Jiang et al., 2015). While the framing model dominated a research, period based on mass media, mass audience, and strong media effects, these foundations are gradually giving way to a new era characterized by media channel expansion, audience fragmentation, and limited effects (Bennett \& Iyengar, 2008; Jiang et al., 2015). Salma Ghanem gives a broader understanding of news framing by identifying four extensions; storyline, main argument, placement, and tone of the theme (Kim et al., 2013). News framing matters in the media field as it has effects on the behavior and mindset of the audiences. Just like political individuals adopt frames from media and fellow politicians, media institutions also inherit specific frames used by elites, citizens, social institutions, and other media organizations. Agenda setting studies focus on the influence involved in the selection of issues that are to be presented in front of the audience, formation of frames depicts media practices in selecting an aspect of information that are used to display issues and events (Kim et al., 2011; Nisbet et al., 2016). Targeting a large audience is also a pressure faced by 
journalists because of which they deliberately select those frames which attract extensive audience response and according to scholars, frames having elements of conflicts, good or bad, evil gather large audience (Kim et al., 2011). Numerous studies have been conducted to access the importance of frames in media according to the impact they have on the audience and the interpretations they extract from those frames. Even though these studies did reveal important revelation regarding frames occurring in news content, but to date, there is no standard established measures to counter similar frames found in news reporting. In framing issues and events that hold national and international importance, there have to be well-established analytical measures to cater to reoccurring frames in news media. Research in framing still works as a contribution to the theory and a method for analyzing media content. The concept of framing implies that communication is a diverse process with multiple phases, including frame-building, frame-setting, and organizational and community framing consequences (Hamdy \& Gomaa, 2012). The importance of framing stems from the fact that it can have an impact on both people and groups as a whole. After being exposed to certain frames, an individual may develop different attitudes. Frames can influence processes such as political socialization and collective action on a societal level. Studying framing of news within this context is important as the audience rely on media and have no direct knowledge of the events happening.

\section{Hypotheses}

Keeping in mind the objective of the study to identify the frames used by Pakistani newspapers in the framing of Indo-Pak armed conflicts after the Pulwama attack in February 2019, the following hypotheses are suggested:

$\mathbf{H}_{\mathbf{1}}$ : Individual responsibility frames dominate most on the editorial pages of the respective newspapers than societal responsibility frames.

$\mathbf{H}_{2}$ : Risk subject matter dominates most on the editorial pages of the respective newspapers than solution subject matter.

\section{Methodology}

To answer the research questions, a quantitative content analyses of frames is done using the Op-Ed sections of six newspapers: The News, Express Tribune, The Nation, Dawn, Daily Times, and Pakistan Today. The main purpose of this study is to identify the frames adopted by respective newspapers in framing armed conflicts post-Pulwama attack. Keeping because of the requirement of this study, the quanti- 
tative content analysis is adopted. In the current study, a census approach was employed to collect sample data, keeping in mind the research focus of the study. The Census method is the method of statistical listing where all members of the population are studied. Through this approach, a subset of data from the population was collected. In the current study, all the editorials and opinions; 1,321 in number published in Op-ed page of six Pakistani English newspapers were studied from which subset of 282 items were selected based on the keywords like Indo-Pak relations, armed conflicts, aircraft, tensions, and equivalents to. Only English newspapers were included in the current research for frame analysis; both Urdu and English newspapers have a national-level presence in Pakistan, but English newspapers are often consumed by policymakers, the corporate community, and the country's urban population. Due to this fact, English newspaper publications were selected so that analysis can be carried out smoothly and effectively.

\section{Inter-Coder Reliability}

Before analyzing and coding data into coding sheets, inter-coder reliability of the subsample was attained. To achieved inter-coder reliability, 50 data items were given to two coders. Both coders were active media persons and were given coding training before filling in sample data for reliability. Inter-coder reliability test was conducted for ensuring a high degree of inter-coder consistency. This was being done to enhance the consistency of data coding the intercoder reliability showed fair agreement between their coding (see table 1 below)

Table 1. Inter-coder Reliability

Tablica 1. Pouzdanost interkodera

\begin{tabular}{|c|c|c|c|c|c|}
\hline & & Value & $\begin{array}{l}\text { Asymptotic } \\
\text { Standardized Error }\end{array}$ & $\begin{array}{l}\text { Approxi- } \\
{\text { mate } T^{b}}^{\text {a }}\end{array}$ & $\begin{array}{l}\text { Approximate } \\
\text { Significance }\end{array}$ \\
\hline Measure of Agreement & Kappa & .889 & .018 & 35.989 & .000 \\
\hline $\mathrm{N}$ of Valid Cases & & 446 & & & \\
\hline
\end{tabular}

\section{Theoretical Framework}

In the following section theoretical framework for the study is established. As evident from the aim of the current study, through this analysis researcher aims at understanding the framing process being adopted by Pakistani newspapers during the Pulwama attack and its aftermath. For analyzing framing categories, frame analysis fits in well with the study's goal. Frames are considered constructs through which the audience develops the meaning of their surroundings. This process is not entirely 
carried out individually but is a part of a broader societal and radical context. Both entities on sending and receiving ends are present in the society and are a part of the framing process (Vossen et al., 2017). This process takes place at multiple levels including journalists shaping content to audience perceiving that content and process with their prior inbuilt values and norms and constructing broader public belief. In describing framing effects on the audience Brüggemann (2014) \& Ireri et al., (2019) considers framing an influential tool to construct information and alter masses' opinion of constructs around them (Brüggemann, 2014; Ireri et al., 2019). Researchers argue that frames have such potential that they can induce specific elucidations while ruling out others. As indicated by studies frames present comprehensive knowledge in simpler form so that audience can make meanings from these frames (Tolley, 2016). According to Goffman framing process includes labelling of "schemata of interpretation" which in turns give audience the ability "to locate, perceive, identify, and label" (Goffman, 1986; Mallouli \& Sweeney, 2019). Keeping in mind the influence of media content on the audience, framing researchers tend to investigate topics that represent value disputes (Jiang et al., 2015). As put forward by Entman et al., (2009) describing the problem, bringing possible solutions, and digging out responsible individuals, and evaluating morally are the key elements of framing (Entman et al., 2009). Due to these elements of framing, Dan \& Raupp (2018) \& Vossen et al., (2017) argue that this framing process depends on the dominant values prevailing in society but are limited due to which frames are also limited and driven by cultural values (Dan \& Raupp, 2018; Vossen et al., 2017). Research has been conducted to assemble information about how a certain frame gathers importance in news media and some fail to catch their position. Scholars have established several aspects that drive the news framing practice, including political influence, social standards, sponsors generating revenue for news outlets, and journalists' capabilities to frame news material (Benford \& Snow, 2000; Carragee \& Roefs, 2006; Valera-Ordaz, 2017). Keeping in mind the bases of framing theory, this study investigates the causal responsibility frame and subject matter of the number of pieces to examine editorials and opinions published by Pakistani newspapers in framing Indo-Pak armed conflict after the Pulwama attack. The framing categories used in the current study are supported by Galtung peace and war journalism frames. In 1986, peace and conflict researcher Johan Galtung presented a model defining two opposing modes of journalism regarding conflicts practiced in media (Galtung, 2016). He uses the term "peace journalism" while demonstrating the model and named two contrasting approaches namely peace journalism and war journalism. Scholars argue that there are two approaches prevalent in media of how a conflict is handled and presented. Either the emphasis is on the root conflict and its peaceful resolution or the violence that is caused after the conflict (Galtung, 2016). While presenting his model Galtung argues that media often follows the low road of emphasizing on the violence and war hyste- 
ria while reporting conflicts and to counter this he promoted peace journalism that focuses on de-escalation of conflicts. Peace journalism stresses on the resolution of conflicts by depolarizing every aspect of both parties involved in conflict and emphasize more on the promotion of peace rather than violence Peace journalism process condemn the repetition of facts that degrade opponent and results in the escalation of conflicts (Lynch, 2014; Siraj, 2016). A comprehensive coding sheet was developed to analyze the content derived from six English newspapers. Using this frame to investigate the framing mechanism used by Pakistani media in covering armed conflicts in the aftermath of the Pulwama attack allows researchers to better understand the media organization approach and various ways to provide context through the selection of specific event frames.

\section{Results}

Table 2 shows the frequency of casual responsibility frames in published items. According to table 1, newspapers published the highest number of items using the Individual responsibility frame. After the Individual responsibility, the societal responsibility frame has less frequency in items than the rest of the frames. The number of items published using the individual responsibility frame is 122 and the societal responsibility frame is 42 . The responsibility frame is used in 56 items, the morality frame is used in 45 items, and the human-interest frame is used in 28 items.

Table 2. Frequency of Causal responsibility frames appeared in post-Pulwama editorials and opinions

Tablica 2. Učestalost pojavljivanja okvira (engl.frame) posljedične odgovornosti u uvodnicima i komentarima nakon napada u Pulwami

\begin{tabular}{|l|c|c|}
\hline Frames & Frequency & Percent \\
\hline Individual Responsibility & 122 & $43.30 \%$ \\
\hline Societal responsibility & 42 & $14.90 \%$ \\
\hline Other & 118 & $41.80 \%$ \\
\hline N & 282 & $100 \%$ \\
\hline
\end{tabular}

Table 3 shows cross tab of Newspapers and Causal Responsibility Frame. As shown in table, while reporting Indo-Pak armed conflict Individual Responsibility Frame was found in greater number of items. Dawn published 13 items, The News published 23 items, Express tribune published 19 items, The Nation published 24 items, Daily times published 32 items and Pakistan today published 11 items based on Individual Responsibility Frame. After Individual Responsibility Frame greater number of items were coded in others category than Societal Responsibility Frame. 
Framing of Armed Conflicts between the Two Nuclear States of South Asia

Table 3. Causal responsibility Frames by newspapers

Tablica 3. Okvir posljedične odgovornosti u novinama

\begin{tabular}{|c|c|c|c|c|c|c|c|}
\hline \multirow{2}{*}{ Frames } & \multicolumn{6}{|c|}{ Newspaper } & \multirow[b]{2}{*}{ Total } \\
\hline & Dawn & $\begin{array}{l}\text { The } \\
\text { News }\end{array}$ & $\begin{array}{l}\text { Express } \\
\text { tribune }\end{array}$ & $\begin{array}{c}\text { The } \\
\text { Nation }\end{array}$ & $\begin{array}{l}\text { Daily } \\
\text { Times }\end{array}$ & $\begin{array}{c}\text { Pakistan } \\
\text { Today }\end{array}$ & \\
\hline $\begin{array}{l}\text { Individual } \\
\text { Responsibility }\end{array}$ & $4.6 \%$ & $8.1 \%$ & $6.7 \%$ & $8.5 \%$ & $11.3 \%$ & $3.9 \%$ & 122 \\
\hline $\begin{array}{l}\text { Societal } \\
\text { responsibility }\end{array}$ & $2.8 \%$ & $2.4 \%$ & $1.4 \%$ & $3.1 \%$ & $1.7 \%$ & $7.0 \%$ & 42 \\
\hline Other & $4.6 \%$ & $6.0 \%$ & $7.8 \%$ & $4.9 \%$ & $7.8 \%$ & $7.0 \%$ & 118 \\
\hline $\mathrm{N}$ & 34 & 47 & 45 & 57 & 59 & 40 & 282 \\
\hline
\end{tabular}

$\mathbf{H}_{1}$ : Individual responsibility frames dominate most on the editorial pages of the respective newspapers than societal responsibility frames.

Table 4 Means of framing categories

Tablica 4. Srednje vrijednosti kategorija uokvirivanja

\begin{tabular}{|c|c|c|c|c|}
\hline & Individual Responsibility & Societal Responsibility & $\mathbf{t}$ & sig \\
\hline Mean & 3.590 & 3.548 & .148 & .066 \\
\hline $\mathrm{N}$ & 122 & 42 & & \\
\hline
\end{tabular}

$\mathrm{H}_{1}$ was tested by comparing means of Conflict $(\mathrm{N}=86$, Mean=3.663) and Solution $(\mathrm{N}=67$, Mean=3.478) framing categories. Significance value (.455) suggests that there is no statistically significant difference between means of the two framing categories, so the $\mathrm{H} 1$ is not supported by the results.

Table 5 Subject Matter Frequency

Tablica 5. Učestalost teme

\begin{tabular}{|l|c|c|}
\hline Subject Matter & Frequency & Percent \\
\hline Risk & 46 & $16.30 \%$ \\
\hline Awareness & 109 & $38.70 \%$ \\
\hline Solution & 57 & $20.20 \%$ \\
\hline War threat & 50 & $17.70 \%$ \\
\hline Regional peace & 20 & $7.10 \%$ \\
\hline N & 282 & $100 \%$ \\
\hline
\end{tabular}

Table 5 shows the frequency of subject matter used in published items. As shown in table 109 items were based on Awareness subject matter showing the highest frequency amongst all. After Awareness subject matter, Solution subject matter was 
Medij. istraž. (god. 27, br. 1) 2021. (29-48)

used in most of the items. 57 items were published based on Solution, 50 were on War Threat and 20 were published using Regional Peace subject matter.

$\mathbf{H}_{2}$ : Risk subject matter dominates most on the editorial pages of the respective newspapers than solution subject matter.

Table 6 Significant mean of hypothesis $\mathrm{H} 2$

Tablica 6. Značajna srednja vrijednost hipoteze H2

\begin{tabular}{|c|c|c|c|c|}
\hline & Risk & Solution & $\mathbf{t}$ & sig \\
\hline Mean & 3.652 & 3.667 & .481 & .894 \\
\hline $\mathrm{N}$ & 46 & 57 & & \\
\hline
\end{tabular}

$\mathrm{H} 2$ was tested by comparing the means of Risk $(\mathrm{N}=56$, Mean=3.652) and Solution $(\mathrm{N}=45$, Mean=3.667) framing categories. Significance value (.894) suggests that there is no statistically significant difference between the means of the two framing categories, so the $\mathrm{H} 2$ is not supported by the results.

\section{Discussion}

Scholars have given special attention to the media's role in conflict and war, with a particular focus on media practices in conflict reporting. Journalists develop frames for complex issues such as wars and conflicts in such a way that they present complex and extensive information in a simplified form that the audience can interpret and understand. Frames diagnose the issues and conflicts, determine what are causes of conflict between the opposite parties, identifying the agents that are responsible for creating the conflict, make more judgments regarding effects of the conflicts, present remedies and take necessary steps for the resolution of conflicts. The purpose of this study was to assess the farming practices used by Pakistani newspapers in reporting on Indo-Pak armed conflicts in the aftermath of the Pulwama attack. Our findings are also following the studies indicating that framing is considered an essential element in news reporting of issues related to conflicts. While reporting two major incidents, Indo-Pak armed conflicts after the Pulwama attack; the Balakot airstrike, and retaliation by Pakistan Air Force, immense coverage was given by print media in documenting every episode that was unfolding as the days were passing after these attacks. Excavating the causes which led to the rising of tension between India and Pakistan, bringing them to the edge of war is an important aspect that was the point of discussion in the analysis. To dig out the factors responsible for the clashes between two Nuclear-Armed Countries, the Causal Responsibility frame was examined in the items published by Pakistani newspapers. Results from the 
Frequency Analysis of Casual Responsibility frame revealed that there was a high percentage of items published by Pakistani newspapers while covering Indo-Pak armed conflicts after the Pulwama attack using Individual Responsibility Frame (see table 1).

The individual Responsibility frame was used by all of the respected newspapers in a massive number of items analyzed in the current study. This authenticates the fact that firstly, all of the respected newspapers used the Causal Responsibility frame in a similar approach emphasizing the Indian Prime Minister (individual responsibility frame) for the arousal of tension between the two countries. Secondly, the use of the Causal Responsibility frame in a larger number of items by newspapers shows that besides emphasizing the conflict itself, journalists took their utmost responsibility to put forward their opinions on various causes of the conflict in front of the audience for their better interpretation of the on-going situation. News Framing tends to include the selection of certain elements of the information making it relevant in the eyes of the viewer so that they understand the situation according to the angle that is displayed in the news frames. In this prospect, the subject matter of the items published by Pakistani newspapers in the framing of Indo-Pak armed conflicts postPulwama attack holds a lot of significance. In the Frequency Analysis of subject matters used in the items published in editorial sections of newspapers, the study found that awareness subject matter dominates with a huge percentage (see table 3 ).

The use of awareness as a subject matter by Pakistani newspapers while analyzing Indo-Pak conflicts demonstrated that journalists not only focused on providing information regarding conflict and events that happened after the two armed conflicts took place, a lot of attention was given in analyzing diverse aspects of the conflict situation and showing readers an unbiased interpretation of the conflicts and making them aware so that audience can understand the situation while knowing all aspects. Secondly, the role of the media specifically print media in building up the public opinions on national and international conflicts is very dominant as they provide a comprehensive analysis of issues of public concern. In this aspect, the journalist's role in the selection of aspects of information and events holds utmost significance and the results of the study also validate that Pakistani newspapers took the responsibility of providing awareness to the readers regarding Indo-Pak armed conflicts with the current situation as well as providing them with the background information.

\section{Conclusion}

The current study was undertaken to evaluate how Pakistani media framed the two armed conflicts between India and Pakistan following the February 2019 Pulwama assault and to help explain this process. To examine also what media frameworks 
were used to frame two main military conflicts. The second objective of the study was to inspect journalism and media's role in armed conflicts. Besides keeping the audience aware of the conflict situation, news media also focuses on providing an in-depth interpretation of the causes of the conflicts. Causal interpretation is an important aspect of conflict framing and digging the root causes of an issue or conflict events is also considered significant. News media is a public forum where issues of national and international affairs, their causes, and solutions are given space, defined, and questioned. media may legitimately address attribution pf responsibility through a confining procedure of framing; characterizing issues, recognizing causes, and recommending solutions, in this way forming popular conclusions about who ought to be considered responsible for causing and taking care of issues (Kim et al., 2002; Zhang et al., 2016). The outcome from our analysis also validates the latter and indicate that Pakistani media did emphasize on interpreting causes and highlighting individuals who serve as resolution factor of the conflict between two neighboring countries. It was observed that Pakistani media incorporated individual responsibility framing while digging out causes of the armed conflicts that spurred put after the deadly Pulwama attack in Jammu and Kashmir. There was seen a consensus among journalists on the fact that the Pulwama attack and its aftermath was pre-planned by the Indian Prime Minister to gain the sympathies of the Indian public in coming general elections. This perception of causal interpretation was widely used by opinion writers and editors in their content to highlight and let the public know about the real intentions behind the conflict. Besides stressing the real cause of conflict, using the frame of causal accountability validates that journalists were well aware of their duty not only to provide conflict-related information but also to expose the parties responsible for taking subcontinent peace to a worsening degree. Taken together, the findings of this research provide insights on the framing process adopted by Pakistani media while reporting two armed conflicts; the Balakot attack and Pakistan retaliation in February 2019. This finding helps to improve the understanding and the application of framework analyses in the context of conflicts. Studies have been conducted to examine framing techniques in democratic, political, economic conflicts between opponents (Post et al., 2018). Jebril et al., (2013) examined the impacts of introduction to human effect and conflict frames in the news on political information (Jebril et al., 2013). Fair \& Hamza (2016) analyzed framing techniques deployed in reporting US drone attacks, but studying framing patterns in armed conflicts is not more prominent specifically in Pakistani media (Fair \& Hamza, 2016). The perspective obtained from this study can help future studies interested in investigating the frameworks of armed conflicts and the framing process used by journalists. A couple of key constraints must be taken into account. The current study has only focused on the editorials and opinions from the Op-ed of newspapers and didn't investigate the news published regarding the Pulwama as- 
Framing of Armed Conflicts between the Two Nuclear States of South Asia

sault. Another shortcoming of the study is that it only includes opinions and editorials of English newspapers and the results cannot be generalized to different language newspapers. Nevertheless, this study put forward many aspects which can be investigated further; I would be interesting to see findings from the examination of editorials and opinions of Pakistani Urdu newspapers. Furthermore, a comparative frame analysis of Indian newspapers and Pakistani newspapers would also be intriguing to investigate.

\section{REFERENCES}

Ahmed, M., \& Ashraf, M. (2019) The Pulwama-Balakot Crisis: A Strategic Assessment. CISS Insight Journal, 7(1), 1-24. http://journal.ciss.org.pk/index.php/cissinsight/article/view/1

BBC. (2019) Kashmir attack: Tracing the path that led to Pulwama. BBC. Retrieved 14 July from https://www.bbc.com/news/world-asia-india-47302467

Benford, R., \& Snow, D. (2000) FRAMING PROCESSES AND SOCIAL MOVEMENTS: An Overview and Assessment. Annual Review of Sociology, 26, 611639. https://doi.org/10.1146/annurev.soc.26.1.611

Bennet, L. (1990) Toward a Theory of Press-State Relations in the United States. Journal of Communication, 40(2), 103-127. https://doi.org/10.1111/ j.1460-2466.1990.tb02265.x

Bennett, W. L., \& Iyengar, S. (2008) A New Era of Minimal Effects? The Changing Foundations of Political Communication. Journal of Communication, 58(4), 707-731. https://doi.org/10.1111/j.1460-2466.2008.00410.x

Bratić, V. (2005) In Search of Peace Media: Examining the Role of Media in Peace Developments of the Post-Cold War Conflicts Ohio University]. Ohio.

Brüggemann, M. (2014) Between Frame Setting and Frame Sending: How Journalists Contribute to News Frames. Communication Theory, 24(1), 61-82. https:// doi.org/10.1111/comt. 12027

Carragee, K. M., \& Roefs, W. (2006) The Neglect of Power in Recent Framing Research. Journal of Communication, 54(2), 214-233. https://doi.org/10.1111 /j.1460-2466.2004.tb02625.x

Carranza, M. E. (2020) Beyond crisis management: the lessons of US interventions in Indo-Pakistani nuclear crises. The Nonproliferation Review, 1-8. https://doi. org/10.1080/10736700.2020.1759855

Chang, T.-K. (1988) The News and U.S.-China Policy: Symbols in Newspapers and Documents. Journalism Quarterly, 65(2), 320-327. https://doi.org/ 10.1177/107769908806500209 
Medij. istraž. (god. 27, br. 1) 2021. (29-48)

Cook, T. E. (2000) Governing with the News: The News Media as a Political Institution. The University of Chicago Press.

Dan, V., \& Raupp, J. (2018) A systematic review of frames in news reporting of health risks: Characteristics, construct consistency vs. name diversity, and the relationship of frames to framing functions. Health, Risk \& Society, 20(5-6), 203-226. https://doi.org/10.1080/13698575.2018.1522422

Dijk, T. V. (2006) Discourse and Manipulation. Discourse \& Society, 17(3), 359383. https://doi.org/10.1177/0957926506060250

Entman, R. M., Matthes, J., \& Pellicano, L. (2009) Nature, Sources, and Effects of News Framing. In K. Wahl-Jorgensen \& T. Hanitzsch (Eds.), The Handbook of Journalism Studies (2nd ed., pp. 175-190). Routledge

Fair, C., \& Hamza, A. (2016) From elite consumption to popular opinion: framing of the US drone program in Pakistani newspapers. Small Wars \& Insurgencies, 27(4), 578-607. https://doi.org/10.1080/09592318.2016.1189491

Feyyaz, M. (2019) Contextualizing the Pulwama Attack in Kashmir - A Perspective from Pakistan. Perspectives on Terrorism, 13(2), 69-74. https://www.jstor.org/ stable/26626867?seq=1\#metadata_info_tab_contents

Galtung, J. (2016) Peace Journalism. Media Asia, 30(3), 177-180. https://doi.org/1 $0.1080 / 01296612.2003 .11726720$

Goffman, E. (1986) Frame Analysis: An Essay on the Organization of Experience. Northeastern University Press.

Hamdy, N., \& Gomaa, E. H. (2012) Framing the Egyptian Uprising in Arabic Language Newspapers and Social Media. Journal of Communication, 62(2), 195211. https://doi.org/10.1111/j.1460-2466.2012.01637.x

Hoxha, A., \& Hanitzsch, T. (2017) How conflict news comes into being: Reconstructing 'reality' through telling stories. Media, War \& Conflict, 11(1), 46-64. https://doi.org/10.1177/1750635217727313

Ireri, K., Chege, N., Kibarabara, J., \& Onyalla, D. B. (2019) Frame Analysis: Newspaper Coverage of Kenya's Oil Exploration in the Post-2012 Discovery Era. African Journalism Studies, 40(2), 34-50. https://doi.org/10.1080/23743670.201 9.1635035

Jebril, N., de Vreese, C. H., van Dalen, A., \& Albaek, E. (2013) The Effects of Human Interest and Conflict News Frames on the Dynamics of Political Knowledge Gains: Evidence from a Cross-national Study. Scandinavian Political Studies, 36(3), 201-226. https://doi.org/10.1111/1467-9477.12003

Jiang, M., Leeman, R. W., \& Fu, K.-w. (2015) Networked Framing: Chinese Microbloggers' Framing of the Political Discourse at the 2012 Democratic National Convention. Communication Reports, 29(2), 87-99. https://doi.org/10.1080/089 34215.2015.1098715 
Framing of Armed Conflicts between the Two Nuclear States of South Asia

Kim, S.-H., Besley, J. C., Oh, S.-H., \& Kim, S. Y. (2013) Talking about bio-fuel in the news. Journalism Studies, 15(2), 218-234. https://doi.org/10.1080/146167 0x.2013.809193

Kim, S.-h., Carvalho, J. P., Davis, A. G., \& Mullins, A. M. (2011) The View of the Border: News Framing of the Definition, Causes, and Solutions to Illegal Immigration. Mass Communication and Society, 14(3), 292-314. https://oi. org/10.1080/15205431003743679

Kim, S.-H., Scheufele, D. A., \& Shanahan, J. (2002) Think about it This Way: Attribute Agenda-Setting Function of the Press and the public's Evaluation of a Local Issue. Journalism \& Mass Communication Quarterly, 79(1). https://doi. org/10.1177/107769900207900102

Kim, Y., \& Jahng, M. R. (2015) Who frames nuclear testing? Understanding frames and news sources in the US and South Korean news coverage of North Korean nuclear testing. The Journal of International Communication, 22(1), 126-142. https://doi.org/10.1080/13216597.2015.1076732

Lynch, J. (2014) Peace Journalism. Hawthorn Press Limited.

Mallouli, S., \& Sweeney, M. S. (2019) The Framing of North Africans by U.S. Print Media during Operation Torch in World War II. Journalism History, 45(1), 6176. https://doi.org/10.1080/00947679.2019.1574179

Marques, F. P. J., Miola, E., Mitozo, I., \& Mont'Alverne, C. (2019) SIMILAR, BUT NOT THE SAME: Comparing Editorial and News Agendas in Brazilian Newspapers. Journalism Practice, 14(9), 1066-1086. https://doi.org/10.1080/175127 86.2019.1684833

Meyer, C. O., Baden, C., \& Frère, M.-S. (2017) Navigating the complexities of media roles in conflict: The INFOCORE approach. Media, War \& Conflict, 11(1), 3-21. https://doi.org/10.1177/1750635217719754

Miglani, S., \& Jorgic, D. (2019) India, Pakistan threatened to unleash missiles at each other: sources. Reuters. Retrieved 21 March from https://www.reuters. com/article/us-india-kashmir-crisis-insight-idUSKCN1QY03T

Mihelj, S., Bajt, V., \& Pankov, M. (2009) Television news, narrative conventions and national imagination. Discourse \& Communication, 3(1), 57-78. https://doi. org/10.1177/1750481308098764

Mitra, S. K. (2001) War and peace in South Asia: A revisionist view of India-Pakistan relations. Contemporary South Asia, 10(3), 361-379. https://doi.org/ 10.1080/09584930120109568

Mukherjee, K. (2013) The Kashmir conflict in South Asia: voices from Srinagar. Defense \& Security Analysis, 30(1), 44-54. https://doi.org/10.1080/14751798.20 13.864868 
Medij. istraž. (god. 27, br. 1) 2021. (29-48)

Mukherjee, K. (2016) Indo-Pak Relations and the Kashmir Problem: From 1947 to the Present Day. Journal of Borderlands Studies, 31(4), 497-520. https://doi.org /10.1080/08865655.2016.1174607

Nisbet, M. C., Brossard, D., \& Kroepsch, A. (2016) Framing Science. Harvard International Journal of Press/Politics, 8(2), 36-70. https://doi.org/10.1177 /1081180x02251047

Pandit, S., \& Chattopadhyay, S. (2017) Coverage of the Surgical Strike on Television News in India. Journalism Practice, 12(2), 162-176. https://doi.org/10.108 0/17512786.2017.1397529

Paul, T. V. (2005) Causes of the India-Pakistan enduring rivalry. In The India-Pakistan Conflict (pp. 3-24) https://doi.org/10.1017/cbo9780511616112.002

Pegahi, N. (2019) From Kargil to Pulwama: How Nuclear Crises Have Changed Over 20 Years. The Washington Quarterly, 42(2), 149-161. https://doi.org/10.10 80/0163660x.2019.1626690

Pegahi, N. (2020) Pakistan's Nuclear Weapons and the Kargil Conflict: Reassessing Their Role in the Two Sides' Decision-Making. Asian Survey, 60(2), 245-264. https://doi.org/10.1525/as.2020.60.2.245

Post, S., Kleinen-von Königslöw, K., \& Schäfer, M. S. (2018) Between Guilt and Obligation: Debating the Responsibility for Climate Change and Climate Politics in the Media. Environmental Communication, 13(6), 723-739. https://doi.or $\mathrm{g} / 10.1080 / 17524032.2018 .1446037$

Rej, A. (2019) S(c)helling in Kashmir: Bargaining under the Nuclear Shadow. The Washington Quarterly, 42(2), 163-186. https://doi.org/10.1080/0163660x.2019. 1627157

Rid, S. A. (2019) Aman ki Asha (a desire for peace): a case study of a people-to-people contacts peacebuilding initiative between India and Pakistan. Contemporary South Asia, 28(1), 113-125. https://doi.org/10.1080/09584935.2019.1666090

Roluahpuia. (2016) Media in conflict or conflict in media: examining media coverage of conflict in Northeast India. Asian Ethnicity, 18(4), 488-504. https://doi.or g/10.1080/14631369.2016.1219224

Schoemaker, E., \& Stremlau, N. (2014) Media and conflict: An assessment of the evidence. Progress in Development Studies, 14(2), 181-195. https://doi.org/ $10.1177 / 1464993413517790$

Sharma, N. (2019) “Qatal Ki Raat”: PM Speaks Of US Claims After Pak Capture Of IAF Pilot. New Delhi Television Ltd (NDTV). Retrieved 13 April from https://special.ndtv.com/us-election-2020-80/news-detail/lok-sabha-elections2019-qatal-ki-raat-pm-narendra-modi-speaks-of-us-claims-after-pakistan-capture-o-2026340/3 
Shoemaker, P. J., \& Reese, S. D. (1996) MEDIATING THE MESSAGE: Theories of Influences on Mass Media Content. Longman.

Siraj, S. A. (2016) Framing War and Peace Journalism on the Perspective of Talibanisation in Pakistan. Media Asia, 37(1), 13-20. https://doi.org/10.1080/01296 612.2010 .11771971

Thesen, G. (2017) An Intervening Intermediary: Making Political Sense of Media Influence. In P. V. Aelst \& S. Walgrave (Eds.), How Political Actors Use the Media (pp. 21-37). Palgrave Macmillan. https://doi.org/10.1007/978-3-31960249-3 2

Tolley, E. (2016) Framed Media and the Coverage of Race in Canadian Politics. UBC Press.

Valera-Ordaz, L. (2017) Frame building and frame sponsorship in the 2011 Spanish election: the practices of polarised pluralism. Contemporary Social Science, 14(1), 114-131. https://doi.org/10.1080/21582041.2017.1347703

Vossen, M., van Gorp, B., \& Schulpen, L. (2017) Thinking and Writing About Global Poverty. Journalism Studies, 19(14), 2088-2107. https://doi.org/10.1080/1461 670x.2017.1316682

Wolfsfeld, G. (2001) The News Media and Peace Processes: The Middle East and Northern Ireland. United States Institute of Peace.

Yusuf, M. W. (2019) The Pulwama Crisis: Flirting With War in a Nuclear Environment. Arms Control Association. Retrieved 10 September from https://www. armscontrol.org/act/2019-05/features/pulwama-crisis-flirting-war-nuclear-environment

Zhang, Y., Jin, Y., Stewart, S., \& Porter, J. (2016) Framing responsibility for depression: how U.S. news media attribute causal and problem-solving responsibilities when covering a major public health problem. Journal of Applied Communication Research, 44(2), 118-135. https://doi.org/10.1080/00909882.2016.1155728 


\title{
Medijsko prikazivanje (framing) oružanog sukoba dviju nuklearnih država Južne Azije
}

\author{
Noor-ul-Ain Shahid \\ Muhammad Ashfaq \\ Javaria Zubair
}

\section{SAŽETAK}

Ovo je istraživanje usmjereno na izvještavanje iz perspektive uzročne odgovornosti i iz perspektive tematike koje su pakistanski tiskani mediji usvojili tijekom oružanih sukoba koji su uslijedili nakon napada u Pulwami koji se dogodio u veljači 2019. Na temelju popisnog pristupa prikupljene su 282 kolumne od ukupno 1321 članka objavljenog u šest engleskih novina. Rezultati pokazuju da se u pakistanskim tiskanim medijima intenzivno upotrebljava perspektiva (okvir) uzročne odgovornosti, a perspektiva društvene odgovornosti upotrebljavala se znatno manje. Analiza sadržaja otkriva da se tema osviještenosti intenzivno upotrebljavala u medijskim sadržajima tijekom i nakon napada u Pulwami. Opažanja se ispituju s aspekta novinarskih preferencija pri odabiru specifičnih perspektiva (okvira) izvještavanja o regionalnim i globalnim oružanim sukobima.

Ključne riječi: oružani sukobi, perspektiva, analiza sadržaja, tiskani mediji, sukobi između Indije i Pakistana, kolumna, Kašmir, uloga medija 